UDC 613.6

\title{
PERIPHERAL BLOOD VALUES IN WORKERS OCCUPIED IN THE PETROCHEMICAL PRODUCTION
}

\author{
G.G. Badamshina, O.V. Valeeva, R.A. Daukaev, D.O. Karimov, A.N. Aslaev
}

FBSI "Ufa Institute of Occupational Medicine and Human Ecology", Russian Federation, Republic of Bashkortostan, Ufa, 94 Stepan Kuvykina St., 450106

\begin{abstract}
The study is devoted to solution of the problems of the early changes detection in a body on the stages, when only the conditions for the pathology formation were created. The analysis of peripheral blood in the workers, occupied in petrochemical production, allowed us to diagnose the changes that testify the body defenses' decrease that occurs under exposure to chemicals. It is shown that in the initial period of exposure to harmful substances the body's reaction to a toxic irritant contain both specific and nonspecific components. The first working years is characterized by the reduction of the number of red blood cells and hemoglobin. Over the next years the gradual stabilization is presented, and then the moderate and persistent increase in red blood indices occur, what indicate on the adaptive nature of the condition.

It was established, that in dependence of the tropism, mechanism of action and the hazard class of hazardous substances, the diverse hematological changes in the body workers are revealed.
\end{abstract}

Key words: hematological values, chemical factor, petrochemical production, benzol, olefin oxides.

Searching for early changes in the body when the conditions for the formation of pathology are just created is an effective method for the detection of diseases associated with working conditions $[1,3]$. It is known that the highly proliferative, multifunctional and morphodynamic blood-forming system extremely rapidly reacts to the different impacts of the harmful production factors [7]. The transient changes in the peripheral blood evidencing the intramedullary response activation can develop in response to the repeated impact of production factors, predominantly, during the first years of contact [1]. If the contact with chemical factor continues, the specific changes in the peripheral blood are developed in human [6]. The peripheral blood composition to a large extent determines the functional and adaptive reserves of body the depletion of which can become the prerequisites for the development of diseases, including the diseases associated with working conditions [4].

The objective of work is to analyse the changes in the peripheral blood indicators in workers occupied in the modern petrochemical production.

We carried out the analysis of hematological in- dicators in 235 workers of petrochemical production. The blood test included the determination of hemoglobin $(\mathrm{Hb})$, number of erythrocytes (Rbc), leucocyte (Wbc), leukocyte count, thrombocytes (Tr), reticulocyte, erythrocyte sedimentation rate (ESR). The formed elements count was performed using the hematological analyzer Sysmax (Japan) [2]. The examined group was represented by males of profession "equipmen operator" the average age of which was $37.4 \pm 1.3$ year, average work experience $-14.6 \pm 0.7$ years. The chemical factor represented by the harmful substances of 2-3 class of hazard was the main factor of working environment. The composition of gas emissions in the air of working zone depended on the stage of technological process. At the styrene production tage the leading role belonged to the aromatic hydrocarbons (AH), at the stage of polyethers production - to the oxides of olefins (OO). The listed substances have the general toxic, irritating and carcinogenic action. In addition, benzene has the impact on the blood and blood-forming organs.

The dutied of equipment operator include control over the operation of equipment, its prepa-

(C) Badamshina G.G., Valeeva O.V., Daukaev R.A., Karimov D.O., Aslaev A.N., 2015

Badamshina Gulnara Galimjanova - Head of the clinical and biochemical laboratory, Candidate of Medical Science (e-mail: gulyabakirova@yandex.ru; tel.: +7(347) 255-19-48).

Valeeva Oksana Vderjeva - biologist of the clinical and biochemical laboratory (e-mail: ovvaleeva1975@gmail.com; tel.: +7 (347) 255-19-48).

Daukaev Rustem Askarovich - Head of the chemical analytical laboratory, Candidate of Biological Science (e-mail: fbun@uniimtech.ru; tel. +7 (347) 255-19-12).

Karimov Denis Olegovich - Head of the laboratory of molecular genetic studies (e-mail: fbun@ uniimtech.ru; tel.: +7 (347) 255-19-48).

Aslaev Azat Nailovixh - Physician (e-mail: karan10@mail.ru; tel.: +7 (347) 255-19-48). 
ration to repair, etc. During the performance of gas dangerous works the maimum concentrations in the air of working zone achied 10 of the maximum permissible concentration. Average shift concentrations of benzene for equipment operators was $9.89 \mathrm{mg} / \mathrm{m} 3$ (MPC $5 \mathrm{mg} / \mathrm{m} 3$ ), ethylbenzene $53.57 \mathrm{mg} / \mathrm{m} 3$ (MPC $50 \mathrm{mg} / \mathrm{m} 3$ ), styrene -10.79 $\mathrm{mg} / \mathrm{m} 3$ (MPC $10 \mathrm{mg} / \mathrm{m} 3$ ), oxides of olefins $-1.36-$ $1.85 \mathrm{mg} / \mathrm{m} 3$ (MPC $1 \mathrm{mg} / \mathrm{m} 3$ ) and complied with class 3.1. The summation coefficients for the harmful substances of the one-directional action in relation to the working conditions of equipment operators comply with class 3.3 [5]. Depending on the chemical substance affecting the body the equipment operators (main group) were divided into two subgroups: I - 149 persons exposed to $\mathrm{AH}$ (benzene, ethylbenzene, styrene), II - 86 equipment operators exposed to $\mathrm{OO}$ (ethylene and propylene oxides). The control group included 168 mechanics on the repair of instrumentation and automation (IA) the working conditions of which belonged to the permissible class (class 2). The average age of IA mechanics is $38.8 \pm 0.7$ years at the work experience of $14.6 \pm 0.7$ years. The groups were comparable under the age and work experience.

To exclude the casuses of anemic syndrome occurring at the background of bleedings and iron deficit the workers of production are examined by surgeon, and for them the analysis of serum iron and ferritin has been performed; to eclude the secondary erytrocytosis - electrocardiography, fibrogastroduodenoscopy, ultrasound examinations of abdominal cavity, retroperitoneal space and small pelvis, irrigography, consultation of procologist. At the combination of increases in the one laboratory indicator by the value exceeding one sigma and disorders detected by the specialists the hematological tests were not performed for the worker.

The statistical processing of obtained data was performed using the set of application programs Microsoft Exel with determining the frequency of deviation of indicator from the standard (P), average error (m), Student's confidence factor (t) and significance level (p). The determinancy of health disorders depending of the work experience is defined using the coefficient of correlation (r).

When comparing the frequency of deviation of hematological indicators from the standard it was established that the red blood indicators were changed more often for the workers of main group $(p<0.05)$ than in the control group (see figure). The erytrocytosis and increase in Hct and amount of $\mathrm{Hb}$ were detected in $7.3,12.5$ and $12.5 \%$ of workers; erythropenia and decreased in the amount of $\mathrm{Hb}$ and Hct - in 5.9, 4.7 and 4.7\%, respectively.

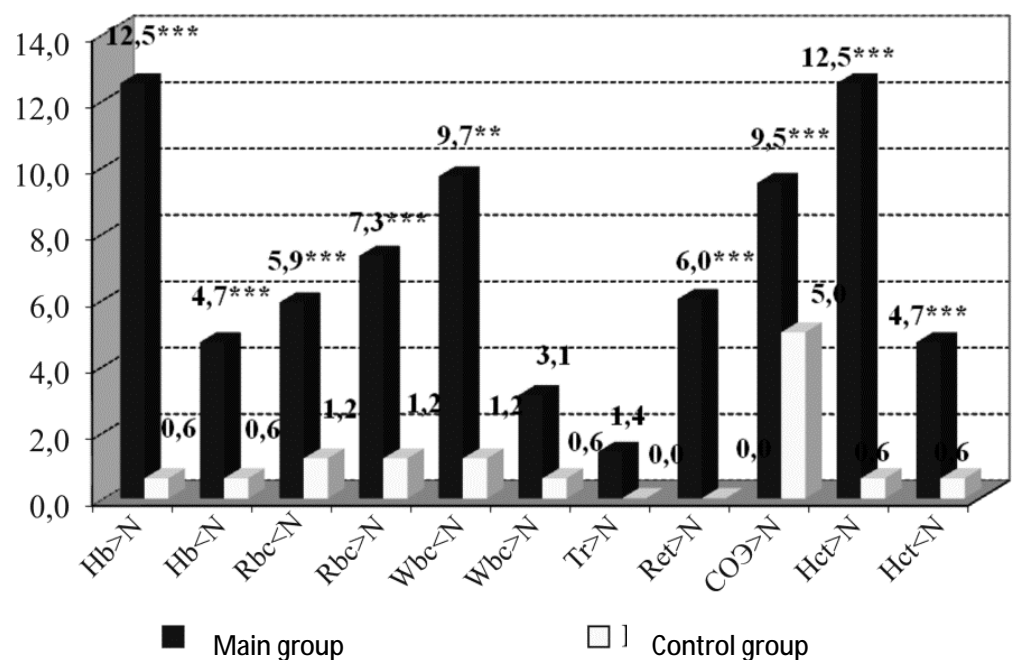

Fig. The frequency of deviations (\%) of the hematological indicators in the workers of polyester resins production: $* *$ - confidence of differences with control group $(p<0.01)$, *** - confidence of differences with control group $(p<0.001)$

The increase of average content $(\mathrm{MCH})$ and MCHC was recorded for 4.3 and $4.7 \%$, the decreased of $\mathrm{MCH}$ and $\mathrm{MCHC}-$ in 8.5 and $11.5 \%$, respectively, since for the workers of control group these disorders are established only in $1.2 \%$ of cases $(p<0.05)$. It should be noted that the imma- 
ture forms of erythrocytes - reticulocytosis are found in all the equipment operators within 1.3$1.8 \%$ in $6.0 \%$ of examined (at standard $0.2-1.2 \%$ ). These disorders, together with leucopenia detected in $9.7 \%$ of workers, can characterize the manifestation of the nonspecific reaction of body in response to the bone marrow irritation with harmful substances of contained in the air of working zone of the production premises.

The leukocyte count analysis demonstrated that the lymphocytosis and eosinophilia were more often detected in the workers of the main group, compared to the data of control group. Increase in the level of eosinophils within 5-13\% was detected in $12 \%$ of workers (at the standard 1-5\%), since in the control group the eosinophilia was detected in $4.8 \%$ of cases, lymphocytosis in the main group in $16.8 \%$ that is by 3.4 times more often than in the control group $(p<0.001)$.

Based on the obtained data in the workers with different work experience at production it is possible to distinguish several stages of the dynamics of hematological indicators (table 1). Blood picture change during the first years of work reflects the manifestation of specific action of chemical substances present in the air of working zone. Thus, the signs of anemia are more often detected in workers with experience of $0-5$ and 6-10 years (decrease in the number of Rbc in and 10.6 and $9.7 \%$, decrease in the level of $\mathrm{Hb}$ - in 6.8 and $12.2 \%$, respectively). The detected negative correlation relationship of anemic syndrome in the form of erythropenia $(r=-0.98)$ and decrease in the amount of $\mathrm{Hb}(r=-0.50)$ with work experience confirms the assumption mentioned above. The anemia developing in the examined persons with small work experience can stipulate the weakening of protective forces in workers that makes them more vulnerable for the development of different chronic non-infectious diseases. In future, when the work experience increases, the increased levels of $\mathrm{Hb}$ and $\mathrm{Rbc}$ are dignosed in the workers that can be associated with the stress of body developed as response to the impact of chemical factor due to hypoxia and mobilization of compensatory mechanisms. The direct correlation dependence of erytrocytosis and increased $\mathrm{Hb}$ level on the work experience is observed ( $r=0.95$ and $r=0.55$, respectively). The eosinophilia recorded in the workers with work experience of more than 15 years (9.8\% of cases) is probably stipulated by the impact of harmful substances having the irritating effect. Increase in the bone marrow regenerative activity indicator which is diagnosed more often at the work experience of 6-10 years (reticulocytosis - in $11.1 \pm 3.3 \%$ ), to a lesser degree - in the workers with work experience of $0-5,11-15$ and more than 15 years $(3.1 ; 7.5$ и $7.2 \%$ of cases, respectively) can develop due to the bone marrow irritation with the toxic products of manufacture. The moderate character of changes in the hematological indicators, depending on the work experience, can be characterized as compensatory and adaptive, and the differences in the character, degree of manifestation and sequence of the development of changes - as the peculiarities of reaction in persons with different work experience as response to the impact of the harmful production factors.

The specific character of impact of chemical substances present in the air of working zone of production is confirmed by the detected changes in the indiators of the clinical blood analysis of workers (table 2). Thus, for equipment operators of I group exposed to the aromatic hydrocarbons, together with leukopenia $(9.8 \pm 2.5 \%)$, we confidently more often found the signs of anemia (decrease in the number of Rbc - in $6.5 \pm 2.0 \%$, decrease in the level of $\mathrm{Hb}-$ in $5.6 \pm 1.9 \%$ of workers) which are probably associated with hemopoiesis disorders due to the blood formation depression when exposed to benzene. The red blood indicators increase was more often diagnosed in II group that can be stipulated by the non-specific blood reactions activation as well as the eosinophilia which probably results from the impact of irritating substances (oxides of olefins) on the workers.

Table 1

Frequency of the hematological indicators deviation in the workers of petrochemical production depending on the work experience $(P \pm m)$

\begin{tabular}{|c|c|c|c|c|c|}
\hline \multirow{2}{*}{ Indicator } & Deviaiton from & \multicolumn{4}{|c|}{ Work experience, years } \\
\cline { 3 - 6 } & standard & $0-5$ & $6-10$ & $11-15$ & More than 15 \\
\hline \multirow{2}{*}{$\mathrm{Hb}, \mathrm{g} / \mathrm{l}$} & $>160$ & $0,0 \pm 0,0$ & $13,3 \pm 4,6$ & $5,9 \pm 2,9$ & $10,8 \pm 1,6$ \\
\cline { 2 - 6 } & $<110$ & $6,8 \pm 2,3$ & $12,2 \pm 3,6$ & $8,9 \pm 3,5$ & $2,7 \pm 1,1$ \\
\hline
\end{tabular}


Risk assessment and management in the occupational medicine

\begin{tabular}{|l|c|c|c|c|c|}
\hline \multirow{2}{*}{ Rbc, $10^{12} / 1$} & $<4$ & $10,6 \pm 1,4$ & $9,7 \pm 3,3$ & $6,8 \pm 3,1$ & $5,0 \pm 1,5$ \\
\cline { 2 - 5 } & $>5$ & $0,0 \pm 0,0$ & $1,4 \pm 1,4$ & $16,9 \pm 4,6$ & $32,8 \pm 3,2$ \\
\hline \multirow{2}{*}{ Wbc, $10 \% / 1$} & $<4$ & $4,4 \pm 1,9$ & $15,5 \pm 4,0$ & $6,0 \pm 1,6$ & $8,6 \pm 1,9$ \\
\cline { 2 - 5 } & $>8$ & $1,8 \pm 1,3$ & $7,1 \pm 2,8$ & $1,5 \pm 1,5$ & $2,7 \pm 1,1$ \\
\hline Eosinophils, \% & $>5$ & $0,0 \pm 0,0$ & $0,0 \pm 0,0$ & $0,0 \pm 0,0$ & $9,8 \pm 4,7$ \\
\hline Segmented neutrophils, \% & $<45$ & $4,3 \pm 4,3$ & $8,3 \pm 8,3$ & $0,0 \pm 0,0$ & $7,0 \pm 3,9$ \\
\hline Lymphocytes, \% & $>40$ & $21,7 \pm 8,9$ & $8,3 \pm 8,3$ & $0,0 \pm 0,0$ & $31,0 \pm 4,1$ \\
\hline Monocytes, \% & $>9$ & $8,7 \pm 6,0$ & $0,0 \pm 0,0$ & $0,0 \pm 0,0$ & $0,0 \pm 0,0$ \\
\hline Tr, 10/l & $>320$ & $0,0 \pm 0,0$ & $8,3 \pm 8,3$ & $0,0 \pm 0,0$ & $0,0 \pm 0,0$ \\
\hline Reticulocytes, \%/л & $>1,2$ & $3,1 \pm 1,8$ & $11,1 \pm 3,3$ & $7,5 \pm 2,6$ & $7,2 \pm 2,0$ \\
\hline ESR, mm H2O & $>10$ & $2,6 \pm 1,5$ & $1,2 \pm 1,2$ & $0,0 \pm 0,0$ & $9,8 \pm 4,7$ \\
\hline \multirow{2}{*}{ Hct } & $>100$ & $0,0 \pm 0,0$ & $13,3 \pm 4,6$ & $5,9 \pm 2,9$ & $10,8 \pm 1,6$ \\
\cline { 2 - 6 } & $<80$ & $6,8 \pm 2,3$ & $12,2 \pm 3,6$ & $8,9 \pm 3,5$ & $2,7 \pm 1,1$ \\
\hline \multirow{2}{*}{ MCH, pg } & $>34$ & $1,5 \pm 1,5$ & $5,3 \pm 3,0$ & $3,7 \pm 2,6$ & $5,3 \pm 3,0$ \\
\cline { 2 - 6 } & $<27$ & $2,9 \pm 2,1$ & $7,0 \pm 3,4$ & $9,3 \pm 4,0$ & $16,1 \pm 5,0$ \\
\hline \multirow{2}{*}{ MCHC, g/l } & $>370$ & $1,5 \pm 1,5$ & $5,3 \pm 3,0$ & $3,7 \pm 2,6$ & $7,1 \pm 3,5$ \\
\cline { 2 - 5 } & $<300$ & $4,4 \pm 2,5$ & $8,8 \pm 3,8$ & $11,1 \pm 4,3$ & $23,2 \pm 5,7$ \\
\hline
\end{tabular}

Table 2

Frequency of the hematological indicators deviation in the workers of the polyester resins production $(P \pm m)$

\begin{tabular}{|l|c|c|c|c|}
\hline \multicolumn{1}{|c|}{ Hematological indicator } & $\begin{array}{c}\text { Deviation from san- } \\
\text { dard }\end{array}$ & group I & group II & control group \\
\cline { 2 - 4 } & $>160$ & $3,6 \pm 2,0$ & $8,0 \pm 3,8$ & $0,6 \pm 0,6$ \\
\cline { 2 - 4 } & $<110$ & $5,6 \pm 1,9^{*}$ & $2,0 \pm 1,9$ & $0,6 \pm 0,6$ \\
\hline \multirow{2}{*}{ Rbc, g/l $10^{12} / 1$} & $<4$ & $6,5 \pm 2,0^{*}$ & $5,4 \pm 3,2$ & $1,2 \pm 0,8$ \\
\cline { 2 - 4 } & $>5$ & $4,8 \pm 1,8$ & $10,8 \pm 4,4^{*}$ & $1,2 \pm 0,8$ \\
\hline \multirow{2}{*}{ Wbc, $10^{9} / 1$} & $<4$ & $9,8 \pm 2,5^{* *}$ & $8,0 \pm 3,9$ & $1,2 \pm 0,8$ \\
\hline Eosinophils, \% & $>8$ & $3,7 \pm 1,6$ & $2,0 \pm 2,0$ & $0,6 \pm 0,6$ \\
\hline Segmented neutrophils, \% & $>5$ & $11,8 \pm 2,7$ & $15,1 \pm 3,9^{*}$ & $4,8 \pm 1,0$ \\
\hline Lymphocytes, \% & $<45$ & $3,3 \pm 3,3$ & $6,7 \pm 6,7$ & $7,7 \pm 1,1$ \\
\hline Monocytes, \% & $>40$ & $16,5 \pm 2,8^{*}$ & $14,0 \pm 3,8^{*}$ & $4,9 \pm 1,7$ \\
\hline Tr, $10^{6} / 1$ & $>9$ & $3,3 \pm 3,3$ & $6,7 \pm 6,7$ & $5,0 \pm 1,7$ \\
\hline Reticulocytes, \%/л & $>320^{*}$ & $1,9 \pm 3,4$ & $0,0 \pm 0,0$ & $0,0 \pm 0,0$ \\
\hline ESR, mm H2O & $>1,2$ & $6,0 \pm 2,0^{*}$ & $4,7 \pm 2,3^{*}$ & $0,0 \pm 0,0$ \\
\hline Hct & $>10$ & $7,1 \pm 2,8$ & $2,0 \pm 2,0$ & $5,0 \pm 0,3$ \\
\hline MCH, pg & $>100$ & $3,6 \pm 2,0$ & $8,0 \pm 3,8$ & $0,6 \pm 0,6$ \\
\hline MCHC, g/l & $<80$ & $5,6 \pm 1,9^{*}$ & $2,0 \pm 1,9$ & $0,6 \pm 0,6$ \\
\hline
\end{tabular}

Note : * - confidence of differences with control group $(p<0.05), * *$ - confidence of differences with control group $(p<0.01), * * *-$ confidence of differences with control group $(p<0.001)$.

Conclusions. For the workers of petrochemical production the changes of hematological indicators in the form of the violations of standards are established in $12.5 \%$ of cases. The detected violations can evidence the decrease in the protective forces of workers body occurring when exposed to the harmful substances of petrochemical production (class of working conditions 3.3). The dynamics of the frequency of deviations of the clinical blood analysis indicators during the whole work experience reflects the body reaction development features. The first years are characterized by the de- crease of erythrocytes and hemoglobin; during the next years the gradual stabilization, and then - the moderate and stable increase in the red blood indicators is observed that evidences the adaptive nature of phenomenon. The changes of hematological indicators in the workers of the polyester resins production characterizes the non-specific body reaction manifestation as response to the irritation of bone marrow with chemical substances and can be the prerequisite for the development of chronic noninfectous diseases. The presence of benzene in the air of working zone together with non-specific 
blood reactions stipulates the development of specific hematological changes in workers that in future can result in the occupational blood diseases development.

\section{References}

1. Zjubina L.Ju., Shpagina L.A., Panacheva L.A. Professional'no obuslovlennye gemopatii i professional'nye zabolevanija krovi [Occupation dependent blood disorders and diseases of blood]. Medicina truda i promyshlennaja jekologija, 2008, no. 11, pp. 15-20.

2. Klinicheskaja laboratornaja diagnostika: spravochnik dlja vracha [Clinical laboratory diagnostics: guide for physicians]. Edit by V.A. Jakovlev. Saint-Petersburg: Gippokrat, 1997, pp. 127-134.

3. Nesmejanova N.N., Sosedova L.M. Doklinicheskaja ocenka rezistentnosti organizma pri vozdejstvii toksicheskih veshhestv [Pre-clinical evaluation of the body's resistance under exposure to toxic elements]. Klinicheskaja laboratornaja diagnostika, 2009, no. 2, pp. 16-19.

4. Volkova S.A., Majanskij N.A., Borovkov N.N. i dr. Pokazateli gemogrammy u vzroslogo rabotajushhego naselenija [Hemogramm values in adult working population]. Gematologija i transfuziologija, 2008, vol. 53, no. 1, pp. 21-27.

5. Rukovodstvo po gigienicheskoj ocenke faktorov rabochej sredy i trudovogo processa. Kriterii i klassifikacija uslovij truda: Rukovodstvo R 2.2.2006-05 [Guidelines for hygienic assessment of the factors of working environment and labor process. The criteria and classification of working conditions: manual P 2.2.2006-05]. Edit by N.F. Izmerov. Bjulleten' normativnyh i metodicheskih dokumentov Gossanjepidnadzora, 2005, no. 3 (21), pp. 3-144.

6. Slepcova A.I., Timasheva G.V., Bakirov A.B. Ocenka pokazatelej klinicheskogo analiza krovi u rabotnikov neftehimicheskih proizvodstv [Evaluation of the clinical blood analysis' values in workers, occupied in petrochemical production]. Bjulleten' Zdorov'e naselenija i sreda obitanija, 2012, no. 11, pp. 12-14.

7. Jesaulova T.A. Gematologicheskij pokazatel' intoksikacii kak marker hronicheskoj intoksikacii u rabotnikov astrahanskogo gazovogo kompleksa [Hematological toxicity index as a marker of chronic intoxication in workers occupied in Astrakhan gas complex]. Fundamental'nye issledovanija, 2008, no. 6, pp. 110. 